\title{
Archaeological textiles excavated at Rayy
}

Jane L. Merritt

\section{(2) OpenEdition}

\section{Journals}

Electronic version

URL: https://journals.openedition.org/tc/323

DOI: $10.4000 /$ tc.323

ISSN: 1952-420X

\section{Publisher}

Éditions de l'EHESS

\section{Printed version}

Date of publication: 1 January 2000

ISSN: 0248-6016

\section{Electronic reference}

Jane L. Merritt, "Archaeological textiles excavated at Rayy", Techniques \& Culture [Online], 34 | 2000,

Online since 26 October 2005, connection on 29 September 2022. URL: http://

journals.openedition.org/tc/323 ; DOI: https://doi.org/10.4000/tc.323

This text was automatically generated on 29 September 2022.

All rights reserved 


\section{Archaeological textiles excavated at Rayy}

Jane L. Merritt 